\title{
THE CHALLENGE OF THEODICY AND THE DIVINE ACCESS TO THE UNIVERSE
}

\author{
THOMAS SCHÄRTL
}

The Catholic University of America

\begin{abstract}
Any new attempt to cope with the problem of theodicy is forced to reinterpret and remodify the classic set of divine attributes. Classical monotheism, at least in the Christian or Islamic tradition, emphasizes the concept of God as a personal, almighty being who is in a completely free relation to the world. However, even within Christianity we find other tendencies which might help us to rewrite the idea that God has some sort of libertarian and unrestricted access to the world. The following article raises the question whether God, as an absolute being, can influence the course of the world directly. The answer to this question has an enormous impact on the problem of theodicy: If God's non-intervention is based on God's essence (rather than any form of initial selfrestriction), then God cannot be held directly responsible for not performing direct acts of intervention.
\end{abstract}

\section{The Battlefield}

Is there any current debate on theodicy? If we put it this way, we have to say that there is always a current debate on theodicy. The problem in question is an everlasting problem for theology and philosophy as well, but the increasing pressure coming from atheistic writers (one might recall the very sketchy and philosophically biased book The God Delusion by Richard Dawkins) forces philosophy and theology to take a look at the problem of theodicy over and over again.

On the other side, a brief look at the contemporary agenda of systematic theology leaves us with the strange impression that the battlefield is already quiet. A large percentage of systematic theologians endorse what is often referred to as the "free-will-approach"; a minority still holds on to other "solutions" of the problem in question. Thus, three parties seem to segregate the area of interest and you can find hardly any compromise

European Journal for Philosophy of Religion i (2009), PP. I2I-I54 
between them. ${ }^{1}$ The contemporary approaches still circle around the so-called free-will-defense ${ }^{2}$ (FWD) on the one side, and around processtheodicy ${ }^{3}$ (PT) and a mystery-approach on the other. In addition to the above mentioned strategies, Friedrich Hermanni has recently proposed a defense of Leibniz's best-of-all-possible-worlds strategy. His considerations may help us to get some valuable insights into certain notions which constitute the backbone of the problem of theodicy. Therefore, it is worthwhile to take a sidestep to examine some aspects of Hermanni's No-Better-World-Theory in addition to a reevaluation of FWD.

Although FWD and PT share a common appreciation of human freedom, they represent rivaling positions and disagree with respect to some crucial issues: free-will-theodicy theorists, like Richard Swinburne ${ }^{4}$ or Alvin Plantinga ${ }^{5}$, emphasize a so-called "classical" concept of God-a concept which tells us that God has to be regarded as an almighty, completely good, benevolent, non-material, omniscient, and perfect person Who is in a free and interpersonal relationship to the world as a creation that emerged out of nothing else but God's initial act alone. So, for the free-will-theodicy theorist, every process-theological account involves either the immediate abandoning of Christian theism ${ }^{6}$, or an almost blatant withdrawal into a dualism which is incompatible with Christian monotheism. ${ }^{7}$ On the other side, for the process-theologian,

${ }^{1}$ As an example, see the appendix in the new edition of Armin Kreiner, Gott im Leid: Zur Stichhaltigkeit der Theodizee-Argumente (Freiburg i.B.: Herder-Verlag, 2005).

${ }^{2}$ Compare as an excellent summary Armin Kreiner, Gott im Leid: Zur Stichhaltigkeit der Theodizee-Argumente (Freiburg i.B.: Herder-Verlag, 1997), 207-319. A more recent version of FWD can be found in Klaus von Stosch, Gott-Macht-Geschichte: Versuch einer theodizeesensiblen Rede vom Handeln Gottes (Freiburg i.B.: Herder-Verlag, 2006).

${ }^{3}$ Cf. David Basinger, Divine Power in Process Theism: A Philosophical Critique (Albany: State University of New York Press, 1988); John B. Cobb and David R. Griffin, eds., Searching for an Adequate God: A Dialogue between Process and Free Will Theists (Grand Rapids and Cambridge: Eerdmans, 200o); John B. Cobb, God and the World (Philadelphia: Westminster Press, I969); David R. Griffin, Evil Revisited: Responses and Reconsiderations (Albany: State University of New York Press, I99I).

${ }^{4}$ Cf. Richard Swinburne, “The Free Will Defence," in Teodicea oggi?, ed. Marco M. Olivetti (Padua: CEDAM, I988), 585-596.

${ }^{5}$ Cf. Alvin Plantinga, God, Freedom and Evil (London: Allen and Unwin, I975).

${ }^{6}$ Cf. William Hasker, "The Problem of Evil in Process Theism and Classical Free

Will Theism," Process Studies 29 (2000): 194-208; Kreiner 1997, I03-I24.

${ }^{7}$ Cf. Kreiner 1997, I03-I24. 
free-will-theodicy is a relic of an old-fashioned metaphysics which is no longer adequate, given the truth of the evolutionary origin of the cosmos and the many accidental events that led to its present stage. Furthermore, the idea of a personal God-which is crucial for freewill-theorists - leads to a much too anthropomorphic picture of God's relation to the world. The classical concept of omnipotence seems to be a dead-end street. Therefore, process-theology is searching for a more advanced metaphysical ground on which the architecture of the Christian worldview can be built- an architecture that is meant to combine the ontological commitments of the natural sciences with the conviction that there exists a loving, caring and calling God in and beyond the universe. Nevertheless, process-theodicy- viewed from the perspective of its results-is just another version of a free-will-defense, though it points to an important and noteworthy strategy: the restriction of God's omnipotence and ability to intervene on assumed metaphysical grounds.

The third group, labeled as "mystery theology," can't be easily categorized or described. One might call it, tentatively of course, the "case of Job." This position permanently puts into question every so called "theoretical solution" of the problem of theodicy. "Auschwitz" remains the key word here, indicating the purely negative result of any attempt to resolve the problem in question. Moreover, this approach holds that any theoretical answer would be a betrayal of those who suffered immeasurable pain in Auschwitz and in other archetypical outcomes of human cruelty. The measureless sufferings experienced during the Holocaust do not only bring into question any theological attempt, they bring into question the trustworthiness of reason itself. ${ }^{9}$ It is not surprising that a more Continental philosophy and theology might support this view; it finds adherents in certain branches of post-idealistic and post-modern philosophy.

${ }^{8}$ Cf. eg. Gerd Neuhaus, Frömmigkeit der Theologie: Zur Logik der offenen Theodizeefrage (Freiburg i.B.: Herder-Verlag, 2003).

9 Cf. Johann Baptist Metz, “Theodizee-empfindliche Gottesrede," in Landschaft aus Schreien: Zur Dramatik der Theodizeefrage, ed. Johann Baptist Metz (Mainz: Grünewald, I995), 8I-IO2. 


\section{Hidden Presuppositions}

The challenge of atheism is written between the lines of the problem of theodicy, though we should be cautious with the assessment of this challenge. How powerful can the force of atheism ever be? It is noteworthy that atheism has a point only when very specific virtues of scientific reasoning are presupposed and acknowledged: for instance, the virtue of avoiding inconsistencies or the virtue of choosing the better alternative among alternative explanations. While the former virtue can be embraced by many people, the latter seems to be obvious only at first glance: What happens if we cannot come up with a better answer to a certain problem? Might an equal response do the job? And, besides, who in the end is accountable for determining the degree of improvement and examining the value of alternatives? It seems too obvious that naturalists, like Dawkins, have a very different understanding of the phrase "better explanation"-different from what theists would call "explanation." And, like it or not, the appeal to universally accepted standards of reasoning seems to create these standards anytime they are needed rather than just referring to something everybody can agree with.

Even with certain standards already in place the problem of theodicy does not lead to atheistic conclusions straightforwardly: Alvin Plantinga, for example, signed off on the virtue of reasonable discourse; and he tried to show, on this very basis of reasonable argumentation, that what atheists claim does not, in fact, really hold: There are no inconsistencies in Christian theism if we correlate the existence of God with the existence of evil because there is no way of transforming the assertion that God exists (as a good, powerful, and omniscient God) directly and conclusively into the idea that the existence of evil has to be rigidly excluded. ${ }^{10}$

${ }^{10}$ Cf. Alvin Plantinga, God and Other Minds: A Study of the Rational Justification of Belief in God (Ithaca and London: Cornell University Press, I990), II5-I30. Plantinga does not deny the existence of evil, but he "forces" the atheist to claim that there are unjustified evils. Connecting a broad notion of justification with a Greater-Good-Defense, which plays the role of a criterion for morality and goodness, Plantinga arrives at an interesting destruction of the assumed inconsistency. 
So, contrary to what is often claimed by atheists ${ }^{11}$ and what is often repeated by theologians, ${ }^{12}$ there is no straightforward inconsistency in our concept of God-even if we have to state that evil exists in the world. Atheists also focus on the problem of evidence: Even if the existence of evil does not contradict the existence of God (as a good, all-powerful, omniscient God) it might, nevertheless, bring into question our belief in the existence of a good, all-powerful and all-knowing God. ${ }^{13}$ But what does that mean? Let us try to understand this position as well as we can by furnishing a possible line of argumentation:

\section{(I) "God" is defined as IQMCN (ID QUO MAIUS COGITARI NEQUIT)}

(2) The property "IQMCN" is explicatively/intensionally identical with the conjunction of the properties $Q, P, R \ldots$ (for example: perfect moral goodness, perfect wisdom and knowledge, unlimited power ...)

(3) If an entity $x$ is missing any of the combined properties (for example $Q$ ) or if it has an opposite property (for example $\neg Q$ ), it cannot be an IQMCN.

(4) Every $x$ 's having a property $Q, P, R \ldots$ is rigorously related to a certain configuration $S$ of states of affairs which itself is the result of the combination of instantiated states of affairs (= events) $p \& q \& r$.

(5) If the states of affairs $p \& q \& r$ are not instantiated or the opposite states of affairs $\neg p \& \neg q \& \neg r$ are instantiated, then the assertion of “ $x$ 's having $Q, P, R \ldots$ " is not allowed, given the common rules of meaningful communication or discursive justification. ${ }^{14}$

${ }^{11}$ It is, however, noteworthy that some atheists concede that there is no contradiction between the assumption that God exists, on the one hand, and the fact that evil exists in the world, on the other; cf. Norbert Hoerster, Die Frage nach Gott (München: Beck, 2007), 87-II3.

${ }_{12}$ Cf. von Stosch 2006, I75-I80.

${ }_{13}$ An echo and caricature of this distinction can be found in Richard Dawkins, The God Delusion (Boston and New York: Houghton Mifflin Company, 2006), Io8-Io9; cf. Hoerster 2007, II3.

14 This version could help us to keep the epistemological tones of an atheistic argument without getting into a deeper analysis of statements that are the scope of certain beliefs. 
(6) The existence of evil is the instantiation of states of affairs such that it is not permissible to call God a perfectly moral being or a perfectly wise or a perfectly almighty being ... ${ }^{15}$

(7) If God cannot be called a "perfectly moral being ..." then He cannot be an IQMCN. And if $\mathrm{He}$ must not be called an IQMCN He is not an IQMCN.

(8) If God is necessarily defined as an IQMCN and He is not an IQMCN, then He cannot exist due to the ontological principle by whose guidance we deny existence to self-contradictorily circumscribed entities.

This argument is in accordance with what a certain version of contemporary atheism has strategically objected. Take, for example, Kai

${ }^{15}$ Of course, one can doubt the "rule of exclusion." It is precisely the range of this rule which is at stake within the contemporary discussions of atheism. But how can we understand this rule? Are there any ways to illustrate it? Let us assume that it is still in accordance with the idea that God is the creator of the universe even if we do not find signs of divine design in evolution but at a certain point we need some configuration of states of affairs which makes belief in God discernible from the belief that no God exists. Some theologians insist that the expansion of the universe points to a beginning of time which supports the so-called cosmological argument. In their view, the expansion of the universe would contribute to a configuration of states of affairs that excludes the belief in a purely random origin of the universe or, at least, in the eternity of our universe. But, of course, it could be harder to find other examples that fit the proposed problem of divine goodness. In the tradition of classic theism the primary attributes of God are trans-categorial attributes. And it could be argued that these attributes aren't subject to the rule sentences $(4),(5),(6)$ allude to. Nevertheless, in defense of sentence (6) one could try to argue for a specific list of special attributes: like God's moral goodness. Theologically, however, classic theism would have to emphasize that God's ontological goodness is the primary focus which the trans-categorially used notion of "goodness" refers to. In other words: Classic theism might not be too impressed by sentences (4), (5), (6) and could easily dismiss the whole threat by pointing to the trans-categorial nature of basic divine attributes. Sentences (4), (5), (6) have to silently presuppose that intrinsic divine attributes are mirrored in relational attributes (which are established upon God's relation to us) and that the rule sentences $(4),(5),(6)$ allude to does apply to these attributes whereby any impact on these attributes is considered to have an impact on God's intrinsic attributes as well. But, this is just a presupposition. One might be able to see how this works for the attributes "being omnipotent" and "being the creator of the universe." But it is much harder to see the connection between "being ontologically good (= all-desirable)" on the one side and being "morally good" ("omni-benevolent") on the other side. 
Nielsen's ${ }^{16}$ examination of crucial phrases used by theists—an examination which was based on certain semantic presuppositions. As pointed out, the abovementioned steps are meant to give some credit to atheistic challenges by getting rid of some of the loose ends one might find in some simpler versions of atheistic challenges. But if we look at the "emperor's new clothes," is the updated version of an atheistic argument better? Is it really convincing? Are its presuppositions written in stone? Any answer to this type of atheism has to emphasize the arbitrariness of the underlying verificationist semantics of sentences (4) and (5). ${ }^{17}$ But in doing so, the achievement of consistency within theism on the one hand might cause a loss of significance on the other hand. From this perspective, belief in God would become just another case of Wittgenstein's "beetle in a box"18.

Although "significance" is a highly disputed concept within the theory of science, to accommodate the atheist's position, we can describe this as:

(SIGN) If we have no criteria for mapping $x$ 's having a property $Q$ to a set of states of affairs, we would hardly see any consequences of $x$ 's having $Q$ in contrast to $x$ 's not-having $Q$ or even to $x$ 's having $\neg Q$.

So, for the sake of the argument, let us assume that SIGN is a valid principle and that (4) and (5) can remain unquestioned, although SIGN breathes the air of Popperian falsificationism and although it is not clear whether such a principle can and should be applied to theistic propositions. But how can we assess proposition (6)? This sentence hardly seems valid. In other words: How does the existence of evil in the world create states of affairs that count against the assumption that we have reasons to call God "good?" As Plantinga pointed out, only if we think that evil is generally unjustified or that the greater good it might serve can be accomplished

${ }^{16}$ Kai Nielsen, “On Fixing the Reference Range of 'God'," Religious Studies 2 (I966): I3-36. These ideas can be found in other, more recent publications of Nielsen; cf. eg. Kai Nielsen, Naturalism and Religion (Amherst: Prometheus Books, 200I).

${ }_{17}$ A critique of verificationism can be found in Plantinga I990, I56-I68.

${ }^{18}$ Cf. Ludwig Wittgenstein, Philosophische Untersuchungen, § 293. 
otherwise, can we create the sort of contradiction an atheist needs. ${ }^{19}$ But, there is no basis for such an assumption. Rhetorically, atheistic strategies sometimes appeal to what one might call a principle of benevolence and compassion which basically says:

(PBC) Any benevolent and compassionate being $a$ would always reduce the suffering of a sensitive person $b$ if $a$ had the means to do so.

This, of course, presupposes that suffering is under any circumstance and regardless of any context something that has to be avoided intrinsically. But, one can question whether we might find a convincing justification of $\mathrm{PBC} .{ }^{20}$ Apart from the vagueness of the key terms, $\mathrm{PBC}$ isn't even unanimously held within ethical disputes. Discussions about the legitimate execution of power for the well-being of many show that PBC can be restricted, even violated, if there is a greater good involved. As a matter of fact, adherents of FWD would follow that route. They would insist that the execution of free will necessarily limits the range of PBC for God. In contrast, PT would focus on the "if"-clause, which is a crucial aspect of $\mathrm{PBC}$. Through a modified understanding of divine omnipotence, PT would be able to stick to PBC, but to question its applicability in the context of theodicy. Either way, since the atheist cannot presuppose that FWD or PT aren't successful in their interpretations of PBC, he/ she might not have a case here.

\section{Neglected Aspects}

The above-mentioned questions, which circle around the applicability of a rule alluded to in sentences (4) to (6) suggest that there might not be an unequivocal understanding of the crucial phrases. The notion of "goodness" is a marvelous example, insofar as divine goodness, at least in a classic sense, does not just exceed moral goodness but surpasses it. Our difficulties in making the specific distinctions or connections might support the idea that a rational response to the problem of

${ }^{19}$ Cf. Plantinga I990, I22-I30.

${ }^{20}$ Cf. ibid. 
theodicy is impossible and that it might be more appropriate to bow our heads in the light of a mystery which is, first and foremost, a conceptual one.

In terms of historical epitomes, we could refer to Immanuel Kant as a sophisticated predecessor who used the notorious ambiguity of certain terms as a basis to establish a very specific mystery-approach. ${ }^{21}$ His considerations, especially of the problem of theodicy, are to be regarded as an early, but very subtle, example of the strategy which is preferred by the third group we described at the beginning. Nowadays Kant's way of dealing with the problem of theodicy has become slightly neglected, and in the context of academic disputes almost forgotten, although Kant's way of handling the problem is in no way irrational or just another example of simply reducing the problem to a theological mystery. It is quite the opposite: On the one hand, in a very detailed and fine-grained manner, Kant disputes the arguments of the rationalistic philosophy and the protestant theology with which he was familiar and which set the agenda at that time. On the other hand, Kant stresses the insolvability of the problem of theodicy without addressing God's mysteriousness directly. To discuss all of his noteworthy insights would require some in-depth analysis. ${ }^{22}$ Instead, let us focus on summarizing the claims Kant made as a result of his considerations. In his treatise Über das Mißlingen aller philosophischen Versuche in der Theodicee Kant writes:

$[U]$ nsre Vernunft [ist] zur Einsicht des Verhältnisses, in welchem eine Welt, so wie wir sie durch Erfahrung immer kennen mögen, zu der höchsten Weisheit stehe, schlechterdings unvermögend. ${ }^{23}$

[Our reason is completely unable to get any insight into the connection which relates the world we know by experience to the highest wisdom.]

We can modify and simplify his argument using a modern language, while keeping the core message, in the following way: Human reason structurally delivers, Kant would have said, two entirely different concepts of wisdom.

${ }^{21}$ Immanuel Kant, "Über das Mißlingen aller philosophischen Versuche in der Theodicee," in $A A$, Vol. 8, 253-27I.

${ }^{22}$ Cf. Richard L. Velkley, Kant as Philosopher of Theodicy (Ann Arbor: University of Michigan, I978); Volker Dieringer, Kants Lösung des Theodizeeproblems: Eine Rekonstruktion (Stuttgart-Bad Cannstatt: Frommann-Holzboog, 2008).

${ }^{23}$ Kant, Über das Mißlingen, 263. 
On the one hand there is a more technical concept of wisdom applicable to the data we experience by observing nature and figuring out laws of nature. For example, the wings of a butterfly or the eyes of a mammal can be called a "product" of technical wisdom insofar as this equipment turn out to be perfectly suited to meet environmental conditions. On the other hand, we are used to dealing with a so-called moral concept of wisdom which is applicable to actions that can then be called "successful" or "good" with respect to a given aim and purpose. These concepts of wisdom, as Kant points out, do not fit together. These concepts have to be treated and applied separately. Otherwise, the result would be a persistent categorymistake and a perennial source of philosophical deception. But when we approach the problem of theodicy, we are necessarily tempted, as Kant would have said, to combine, even to fuse both concepts by wondering whether the structure of the world, which allows room for any kind of evil, can be the result of God's (moral) wisdom. But, as Kant would have added, we should not yield to temptation whenever the consistency of reason is at stake.

Let us try to clarify Kant's point with the help of some distinctions. Therefore, let us elucidate the term "wisdom" by using the phrase "orderly" and suggesting the following:

(O) The occurrence of an event-token $e$ is an "orderly" occurrence if and only if there is a structure $S$ such that the occurrence of $e$ is a means $m$ related to a certain end $G$ and the means-end relation is governed by $S$ for any event-type $\varphi$ for which $e$ is a token.

From here we can define two senses of "orderly" in order to come closer to Kant's problem and verdict:

(NO) The occurrence of an event-token $e$ is a natural-orderly occurrence if and only if there is a natural structure $S^{*}$ such that the occurrence of $e$ is a means related to a certain end $G^{*}$ and the means-end relation is governed by $S^{*}$ for any event-type $\varphi$ for which $e$ is a token.

(MO) The occurrence of an event-token $e$ is a moral-orderly occurrence if and only if there is a moral structure $S^{* * *}$ such that the occurrence 
of $e$ is a means $m$ related to a certain end $G^{* * *}$ and the means-end relation is governed by $S^{* * *}$ for any event-type $\varphi$ for which $e$ is a token.

It is apparent that we are dealing with two different senses of "orderly" here. And this causes, as Kant underlines, further problems for our understanding. In particular, evil events (and first and foremost natural evils) seem to fulfill the requirements of NO. "Orderly," in a moral understanding, means "good." It seems to be obvious that evil events do not fulfill that standard. Yet, the solution of the problem of theodicy requires nothing less than the applicability of $\mathrm{NO}$ and $\mathrm{MO}$ to events in the universe once we believe that God is the ultimate "governor" of the universe. To believe in God as the wise governor of the universe implies, following Kant, that an event $e$ is natural-orderly and moral-orderly simultaneously. Since we hesitate to call evil events moral-orderly and to simply conflate $\mathrm{MO}$ with $\mathrm{NO}$, we are left with a puzzle: It seems to be the case that we don't really understand what we mean by God's wisdom and that we don't understand how NO and $\mathrm{MO}$ are related to each other once we approach the problem from God's point of view.

So, do we have to end our considerations at this point? Admittedly, it is far from being intellectually satisfying to confess that the conceptual paths we follow are not made to lead us towards higher ground. But satisfaction, so Kant reminds us, is no intellectual motive at any rate. Why should we take any further steps? Why should we try to leave Kant behind? How can this be accomplished? The post-Kantian tradition could help us with a very bold piece of advice: There are questions that have to be answered, even if the answers are not in a position to count as ordinarily justifiable knowledge. ${ }^{24}$ These answers, presented in a speculative manner, have to be given to sustain the nature of reason itself. Since reason is in charge of integrating the plurality of experiences and concepts into the unity of a so-called unifying idea, reason will not get rid of the task of giving a well-developed answer, even to merely speculative questions. Speculative questions reveal patterns which indicate the necessity of conceptual unification. It would mean a threat to reason

${ }^{24}$ Cf. Dieter Henrich, "Grund und Gang spekulativen Denkens," in Berwußtes Leben: Untersuchungen zum Verbältnis von Subjektivität und Metaphysik, ed. Dieter Henrich (Stuttgart: Reclam, I988), 85-138. 
itself if we were to leave the gap between the concepts involved (the connection of $\mathrm{NO}$ and $\mathrm{MO}$ and God's wisdom) completely unabridged, since we have to understand ourselves as unified and unifying identities, and since we experience the necessity of combining so-called technical, event-related wisdom with pure moral, action-related wisdom through the fact that we are embodied persons, "minds dipped in matter and matter dipped in spirit." We are inhabitants of both the natural and the moral realm. The same is true for the problem of theodicy: We are in need of unifying concepts to bridge the difference between pure natural and pure moral wisdom, as we do in other areas of theistic concept-formation, to bridge the gap between causality and teleology, between agents and events.

Still, Kant's warnings seem to be valid: Since we are in no position to explain the meaning - the meaning relative to a divine perspective-of single events and their contribution to a presumed ultimate goal of the universe, our considerations must remain somewhat speculative and fragile. In other words: We might only be able to point to goal-types $\gamma$ for event-types $\varphi$ by referring to a very speculatively described superstructure $S$ ' (which must then be portrayed as something that unifies the moral and the natural realm), but we might not be able to indicate the concrete means-end-function $G(m)=e$ for a concrete (evil) event-token $e .{ }^{25}$ For the sake of a label, let's call the restrictedness of our abilities "Kant's ghost," who might haunt us every once in a while.

\section{Overestimated Strategies}

Two highly advanced strategies, which claim to offer profound reasons for negating sentence (6) in the atheist's argument, turn out to have the same problem in common. At a certain point, both the Free-WillTheodicy and the No-Better-World-Theodicy deal unavoidably with modal operators. This is apparent for the No-Better-World-Theodicy

${ }^{25}$ Especially the latter is the more important concern for a First Person Perspective on natural evil. In the light of a certain catastrophe one is inclined to ask: Why did this happen to me, why did it happen now? The occurrence of certain evil-tokens is part of the questions we ask when we face the problem of theodicy from a First Person Perspective, as opposed to only from a Third-Person-Perspective. 
as this is presented in Friedrich Hermanni's book. ${ }^{26}$ It is not so obvious for FWD unless we take a closer look at the topological architecture of their argument: The Free-Will-Theodicy tries to answer the question: "Why is there any evil in the world?" by pointing out that evil is a consequence of human freedom and that natural evil, which, of course, cannot be a consequence of human action, is the presupposition for inductively gained knowledge of natural laws and their influence on human intention, action and will. ${ }^{27}$ The Free-Will-Defense is connected to a Laws-of-Nature-defense in the end.

Yet FWD has, as one could call it, a problem with divine morality. Whenever they are asked: "Why does God not intervene in the course of nature?" the Free-Will-Theorist has to answer: The only reason why God does not intervene is because of his respect for human freedom and his desire to guarantee it. The existence of freedom (to be more precise: the possibility of carrying out free acts) is a higher value than any stage of the world that would be a result of God's initiative in protecting us from the bad consequences our actions bring about. But, one might ask, would not the horrifying amount of suffering experienced during the Holocaust and the Second World War, at the very least, provide a certain context in which the value of freedom would be reasonably exceeded by the value of compassion? Wouldn't a reasonable being have turned from non-intervention to intervention, guided by the value of compassion under circumstances where human cruelty endangers the conditions of freedom itself? Wouldn't it have been a low price for God to pay to support Graf von Stauffenberg's attack on Hitler with better effort, even if it may have been God's intention not to bring about too many miracles, which have the tendency to turn a human being's "will to believe" into the force of assent to knowledge ${ }^{28}$ Even if God wanted to stay behind the scenery,

${ }^{26} \mathrm{Cf}$. Friedrich Hermanni, Das Böse und die Theodizee: Eine philosophisch-theologische Grundlegung, (Gütersloh: Kaiser, 2002).

${ }^{27}$ Cf. Richard Swinburne, The Existence of God, $2^{\text {nd }}$ edit. (Oxford: Clarendon Press, 2004), $236-272$.

${ }_{28}$ The No-Enforcement-of-Faith-Principle (NEFP) is a very tricky principle. It can be misused in a number of ways. One example is the creationist's response to the material evidence scientists put forward to justify a Darwinian theory of evolution. The creationist might point out that this evidence was placed in the soil of the earth by God himself in order to make it harder for us to believe since, otherwise, the handwriting of the creator would have been too obvious and we would have been "forced" to believe in God. Well, 
he could have done so very easily by hidden, i.e. unobservable, effects of his power. If any Free-Will-Theorist tries to answer the question why the value of freedom is always (and this implies: regardless of any special circumstances $^{29}$ ) higher than the value of compassion, he/she cannot help but declaring, at last, that God's specific intentions and preferences are a mystery. In the end the Free-Will-Theodicy collapses into a MysteryTheodicy by pointing to the incompatibility between human and divine values.

Furthermore, the problem of natural evil is not touched at all by any declaration of God's respect for human freedom. If natural evil is a result

it is hard to see whether NEFP is really needed-given a careful analysis of the act of faith as an act of human freedom and human autonomy. But what is more disturbing about NEFP is that one could be forced to assume that God willingly plays tricks with us in order not to violate NEFP. It might be noteworthy to point out that such an idea is unacceptable within a Catholic framework in relation to the concept of God. Within such a framework the idea that God is the source of reason (including human reason) is still powerful. A God who willingly deludes human beings in their endeavours, including (scientific) reasoning, seems to be a highly problematic idea. But, of course, this remark does not prove that NEFP is wrong. It just points to certain unwelcome consequences arising from it. For the application of NEFP to outcomes of divine action see Klaus von Stosch, Einführung in die Systematische Theologie (Paderborn: Ferdinand Schöningh, 2006), 85. Von Stosch's use of NEFP seems to be necessary to keep the "epistemological" freedom of the act of belief. On the other side, if God's action is ambiguous and does not produce evidential clarity then God's action cannot be distinguished from non-action (at least from an epistemological point of view). But then, do we have any criteria to identify God's actions at all?

${ }^{29}$ It might be noteworthy to mention that even in a secular context- the context of legal enforcement of governmental power-almost everybody would agree to the legitimacy of restricting human freedom whenever a greater good (the well being of others, an un-endangered performance of justice etc.) is at stake. It seems to be the case that the freedom of a mass murderer has more value according to a FWD than the freedom of the victim that falls prey to the murderer. To avoid these consequences FWD has to embrace a version of "open theism" which consequently denies divine foreknowledge and, therefore, would have to point to the risky situation an omnipotent being ( that is deprived of foreknowledge) would have to face if it didn't bind itself strictly to a policy of non-intervention. But such a God-as contemporary critics of open theism point out-would be poorer than any human being that finds itself called to compassion and, therefore, intervention. See von Stosch 2006, 55, FN III. Von Stosch seems to embrace open theism although his appreciation is expressed within the context of a temporalist notion of God's eternity. For "open theism" compare Clark Pinnock et alii, The Openness of God: A Biblical Challenge to the Traditional Understanding of God (Downers Grove: Inter Varsity Press, 1994). 
of the laws of nature God has "designed" for the universe why is it that God could not come up with "better" (let's say: less "bloodthirsty") ones? And if natural evils aren't by any means strictly logical implications of the laws of nature, but occasional occurrences of events which are in accordance with these laws, why does God not intervene at least at certain points in history to prevent the total extinction of species or the killing of people instead of sacrificing them to the blind powers of nature? ${ }^{30}$ Is it valid to say, as some philosophers and theologians do, that the laws of nature are a presupposition of human freedom? ${ }^{31}$

But if freedom in nature is a prerequisite for human freedom, then it seems unavoidable for us to overstretch the notion of "freedom" a little bit - applying the Principle of Alternative Possibilities (which is valid for human libertarian freedom) - to development in nature and to the entities that are involved in this development. ${ }^{32}$ It is clear that PT's metaphysics (in a Whiteheadian sense) could support such a move, but would FWD be willing to sign off on that as well?

Let us focus once more on the above mentioned claim that natural evils are unavoidable. Any adherent of FWD is more or less forced to say that:

I) Natural evils are a result of the Laws of Nature-of those laws which

2) God chose to ensure the possibility of human freedom.

${ }^{30}$ Cf. Hoerster 2007, 94 .

${ }^{31}$ For this position compare von Stosch 2006, 264 and 268.

32 The overstretching of the notion of "freedom" has to be justified, of course. Per se the application of PAP to non-human nature seems to induce category-mistakes unavoidably. This is part of the reason why process metaphysics have to come up with an almost extravagant vocabulary. But neither a neologistic understanding of freedom nor the overstretched application of PAP will justify the idea that the laws of nature that allow certain natural evils are a necessary prerequisite for human freedom. These maneuvers are only tools and need the support of another principle. It would have to be the idea of an Impossibility of Emergent Attributes (IEA). IEA plays a basic role in a naturalistic and materialistic explanation of human consciousness. It is used to question the non-physical nature of mental phenomena. In the hands of PT, IEA would become a reverse tool to implement a pan-psychistic ontology which allows the ascription of certain mental qualities, phenomena, and attributes to non-human entities. IEA itself is, in the end, based on the intuition of the homogeneity and the unity of everything that exists. 
It is, at first glance, not so easy to explain what one could mean by "result," although this seems to be the cornerstone of $\mathrm{I}$ ). "Result" is a very ambiguous term. To illustrate this let us take a look at an analogy: After extensive grocery-shopping, I take a look at the bill. I might get the impression that the result is shocking or, at least, disturbing. The bill is in a way the result of laws of mathematics (very primitive ones: simple laws of algebra and calculation). The final number on the bill, however, is the product of my undisciplined shopping behavior; it is the product of certain events and the application of mathematical laws. The same is true for natural evils. If we want to know why there is natural evil in the world (take a hurricane or an earthquake as examples), we won't be satisfied with an answer that points to the laws of nature. The evil in question is the product of certain events which served as antecedents of a causal connection that is based on the laws of nature. The natural evil that bothers us is not the product of the presupposed law of causality itself. A comparable ambiguity can be found in claim 2): What does it mean to say that the laws of nature that include the possibilities of natural evil are presuppositions of human freedom? Presumably, claim 2) alludes to the "necessity" of chance and occasion or-in other words- the "necessity of possibilities." However, this answer does not satisfy anybody who wants to know why a certain event in nature is a presupposition of human freedom or, to be a bit more precise, a necessary presupposition for the possibility and development of human freedom. The laws of nature and the realm of possibilities would still remain untouched and unquestioned if none of the natural catastrophes we are able to recall ever happened.

We can use a more prominent terminology to describe the problems of a Natural-Law-Defense: Let $\boldsymbol{N}$ be a set of possible Worlds which are possible by laws of nature. Presumably, it could be agreed that $N$ is smaller than $L$, which is the set of all logically possible worlds, since we don't have good reason to believe that $N$ is co-extensional with $L$. Now, for all worlds $w_{\alpha}, w_{\beta}, \ldots w_{\omega}$ in $N$, natural evil is just a probability, which means that natural evil occurs in some worlds of $N$, but not in all worlds. To put it in a nutshell: Whenever natural evils occur in $w_{\alpha}$ they do not occur in, for example, $w_{\omega}$ (otherwise the occurrence of natural evils would be natural-law-necessary). If $w_{\alpha}$ is identical with our actual world $\alpha$, which is a world in which many natural evils have occurred and will occur, and if it is true that evil does not occur in, for example, $w_{\omega}$, then the question 
must arise why $w_{\alpha}$ is the actualized world and not $w_{\omega}$. If an answer to that question points to the idea that $\alpha$ would be identical to $w_{\omega}$ only if God had interfered with the course of $w_{\alpha}$ several times, then in saying this, we would have to deal with the very same question that bothered us while we took a look at the value of human freedom within the context of FWD: Does God have good reasons for his non-intervention? Why is God interested in having $w_{\alpha}$ as $\alpha$ and not any other world or, at least, not $w_{\omega}$ ? There is nothing in the way $N$ is furnished that prevents $w_{\omega}$ from being identical with $\alpha$. These questions and remarks fit precisely with Immanuel Kant's verdict. Kant would have repeated his core message: We may explain certain atrocities in nature as the outcome of the design of the laws of nature; nevertheless, we don't understand why a specific atrocity had to occur and what the specific event's position really is within the whole "story" of the universe (a story that means to "ensure" the outcome of human freedom). The situation becomes more complicated again once we ask whether a certain evil event in nature could have been prevented by divine intervention. Kant's "ghost," the problem of ambiguity and non-understanding, is starting to "haunt" us again.

In contrast to FWD the No-Better-World-Theory argues in a more aprioristic mode because the unsurpassable quality of the actual world is deduced from divine attributes only: If God exemplifies unsurpassable greatness, it is impossible for Him not to bring the best of all possible worlds into existence. Therefore, the actual world $\alpha$ must be the best of all possible worlds. Since our actual world includes evil and suffering, the events producing or carrying evil must be regarded as integral parts of the course of the best possible world. Friedrich Hermanni tries to support this view by declaring that the chain of events in the actual world is logically necessary for our world to be the best of all possible worlds. ${ }^{33}$ At this point, one can see that the special problems of the No-Better-World-Theory are somewhat easier to identify: The empirically describable form of the actual world $\alpha$ seems to be of no interest to this theory. In other words: This theory expresses an extraordinary blindness to the suffering in the actual world. Furthermore, one will uncover logical problems in what Hermanni wants to tell us: To regard a specific chain of events as a logical necessity (translating this claim into the language of possible-worlds) implies that

\footnotetext{
${ }^{33}$ Cf. Hermanni 2002, 266-29I.
} 
apart from the actual world $\alpha$, no other world, in which the mentioned chain of events does not occur, is an element of the set of possible worlds (which must mean logically possible worlds) $L$. But, why must we think that there cannot be any other world equipped with alternative chains of events? If there is no reason to restrict alternative courses of events, then the course of events in our actual world $\alpha$ cannot be declared a logical necessity; perhaps one might call it a necessary condition for realizing the end God intended to be realized. And perhaps this interpretation is more adequate to Leibniz' basic idea, but necessity-related-to-aim is just functional and not logical necessity. Furthermore, one could argue as follows: As long as we are able to conceive alternative courses of events, there are alternative courses of events which constitute other possible worlds. And as long as we still have the ability to conceive alternative chains of events, bringing about less suffering and evil, we can imagine an alternative possible world which is better than the actual world. Although conceivability might not always be a good criterion of possibility, it might, at least, do the job of overriding the assumption that evil is a necessary component of our actual world $\alpha$. On a more intuitive basis, it is hard to see how the enormous amount of evil in our actual world can contribute to the marvelous rank it seems to have in God's eyes-given that alternative courses of events could have been set into motion. ${ }^{34}$

Discussions like this, moreover, reveal that Kant's "ghost" continues to haunt us: The No-Better-Worlds-Theory actually presupposes that worlds are comparable on the basis of some sort of goodness or quality. But this causes a problem that leads to a dichotomy of categorization which resembles Kant's verdict. The precise cause is a set-theoretical problem. Within ethical discussions and with respect to the problem

${ }^{34}$ Of course, the problem of natural evil is usually approached from a different angle as well. Swinburne offers some additional motives to "defend" the existence of natural evil: I) Natural evils are a way to improve our inductive ways of gaining knowledge. 2) Natural evils are an important occasion to perform acts of mercy and compassion; and they provide occasions to perform super-erogatory acts. Cf. Richard Swinburne, Providence and the Problem of Evil (Oxford: Clarendon Press, 1998), 160-I92. Although Swinburne is right in pointing to these aspects it is still hard to see how this strategy might justify the number of natural evils and their rather disastrous consequences. Furthermore, justifications like the above-mentioned approach natural evils from a Third-Person-Perspective only. For the victims of natural catastrophes and terminal diseases the indicated defense strategies may have no bearing, no relevance, and no impact. 
of theodicy, the use of the terms "good" or "better" is related to actions and events that are implied by actions. ${ }^{35}$ Events are instances of states of affairs and are, therefore, elements of worlds (worlds seen as sets in a very broad understanding of possible-worlds-semantics). It is not without reason to think that qualifications which are ascribable to elements of sets are, nevertheless, not ascribable to the set in question. For example, the set of all red entities in Berlin is not red. It seems to involve a category mistake if we want to use the mentioned qualification for both the elements and the set. If these preliminary considerations are right, then we bump into the above mentioned problem or become haunted by Kant's "ghost." The problem we are facing has the structure of a dilemma. Either:

(I) We are not permitted to call a world good or better for set-theoretical-reasons.

(2) Or, we are permitted to use the terms in question and we can call the actual world the "best of all possible worlds." We would then have to clarify the "goodness" of the actual world by determining $G(m)=\alpha$ [in contrast to, let's say, the $G(m)$ for other possible worlds $\left.w_{\beta}, w_{\gamma} \ldots w_{\omega}\right]$.

So, even if we can sneak around I) Kant's ghost will catch us at alternative 2). We simply have no clue why our actual world (with all its atrocities etc.) is the best of all possible worlds. We have no idea what the specific ends of the atrocities are, and what the overall end of the course of events in the actual world really is. Without such a clue, the comparison of worlds remains useless. Thus, the claim that this world is the best of all possible worlds is nothing else but a claim.

What kind of problem do the above-mentioned strategies have in common? Both strategies, in one way or the other, share the view that it is necessary to restrict God's doing and deciding by an appeal to "certain necessities."To answer the question: "Why did God not intervene?" both theories point to a certain limitation of omnipotence. The only restricting modality FWD can offer is some kind of moral necessity with respect to human freedom: To enable human freedom, God is morally obliged not

\footnotetext{
${ }^{35}$ Cf. Hoerster 2007, 90.
} 
to intervene in the course of the actual world. With regard to natural evil Free-Will-Defense-theorists are tempted to base the validity of natural laws on logical necessity. But this is just a vague hypothesis. ${ }^{36}$ In contrast, the No-Better-World-Theory prefers logical necessity to explain why God couldn't change the course of the actual world by intervention. But, as already noted, this assertion is hardly convincing because to exclude any alternative chains of events from being realized in other possible worlds means to restrict the sphere of possibility and to narrow it down to a very small set, including the actual world $\alpha$ as the only element. Since one may find no reason for doing so and since every restriction of the same sort would lead to a collapse of possible-worlds-talk, the strategy in question is a dead end.

Despite these problems, both strategies reveal an important aspect: To accommodate the question: "Why did God not intervene?" every answer has to deal with some sort of limitation of God's omnipotence. How can this be achieved? A necessary, but not completely satisfying, starting point would have to admit that God's decisions are restricted by logical impossibility. ${ }^{37}$ For example, God is not able to create round squares. Even the widest interpretation of omnipotence would concede that God's omnipotence is limited by God's nature. Therefore everyone who is asked whether God has the ability to $\sin ^{38}$ can answer very clearly: "No." If we call this kind of necessity a metaphysical or conceptual necessity

${ }^{36}$ Cf. von Stosch 2006, 259-269. Von Stosch examines the idea that the Laws of Nature could not have been different from what they are as a matter of fact. Although there is no scientific support for a "No-Better-Laws-of-Nature-Theory" (NBLNT), he wants to stick to this idea, at least for the sake of a hypothesis. But even a merely hypothetical use of a NBLNT is nothing else but a sophisticated version of a No-BetterWorlds-Theory. Any criticism that challenges a No-Better-World-Theory will challenge the NBLNT as well.

${ }^{37}$ As a basic introduction to the problems and ranges of omnipotence see Anthony Kenny, The God of the Philosophers (Oxford: Clarendon Press, I979), chapter 7; cf. Armin Kreiner, Das wahre Antlitz Gottes - oder was wir meinen, wenn wir Gott sagen (Freiburg i.B.: Herder-Verlag, 2006), 308-316.

${ }^{38}$ Usually William of Occam is referred to as a representative of a fairly wide interpretation of omnipotence. However, detailed research supports a more careful assessment. Cf. Hubert Schröcker, Das Verhältnis der Allmacht Gottes zum Kontradiktionsprinzip nach Wilhelm vom Ockham (Berlin: Akademie-Verlag, 2003) 200-206, 502-508; for the outline of the problem cf. Nelson Pike, "Omnipotence and God's Ability to Sin," American Philosophical Quarterly 6 (I969): 208-216. 
we can add: God's omnipotence is limited by metaphysical necessity as well. Metaphysical necessity is a much stronger modality than moral necessity or natural-law-necessity, although metaphysical necessity is somewhat weaker than logical necessity. Since logical necessity is only formal, metaphysical necessity is the strongest content-providing modality we can propose. So, if we managed to furnish an argument dealing with metaphysical necessity with regard to God's non-intervention, we would be able to deal with the problem of God's responsibility, despite the existence of evil.

\section{God's Relation to the World}

Before we turn to the last part of our considerations it is important to develop an overview of the differences and degrees of possibilities (and, along the same lines, impossibilities and necessities). Although in philosophical literature one will discover a highly advanced debate on how to distinguish (or not to distinguish) the spheres of possibilities, it is hardly deniable - at least on a more intuitive basis - that there are significant gradual distances between logical, metaphysical and naturallaw-possibilities if one is willing to base possibility on conceivability (but, of course, not every philosopher is willing to agree with this).$^{39}$ In contrast, moral possibility or impossibility is a vague conception. Its meaning and range can be strengthened only if we anchor it in conceptual or metaphysical necessity.

Let us illustrate the extension of possibilities with the help of some examples that offer insight by approaching the opposite direction: impossibility. We can distinguish logical impossibility from conceptual impossibility, conceptual impossibility from mere metaphysical impossibility, and metaphysical impossibility from laws-of nature-impossibility. Different possibilities and impossibilities represent different kinds of

${ }^{39}$ For further discussion see Stephen Yablo, "Is Conceivability a Guide to Possibility?" Philosophy and Phenomenological Research 53 (1993): I-42; Tamar Szabó Gendler and John Hawthorne, eds., Conceivability and Possibility (Oxford: Clarendon Press, 2002); Uwe Meixner, The Theory of Ontic Modalities (Frankfurt and Paris: Ontos-Verlag, 2006), $40-52,152-156$. 
limitations within the logical sphere of possibility. ${ }^{40}$ Take, for example, the following propositions:

$\begin{array}{lll}\text { \# I: } & \begin{array}{l}\text { It is not possible to claim } p \text { and } \neg p \\ \text { in the same proposition. }\end{array} & \begin{array}{l}\text { Logical } \\ \text { impossibility }\end{array} \\ \text { \# 2: } & \begin{array}{l}\text { It is not possible for a dolphin } \\ \text { to walk around. }\end{array} & \begin{array}{l}\text { Conceptual } \\ \text { impossibility }\end{array} \\ \text { \# 3: } & \begin{array}{l}\text { It is not possible for a (temporally } \\ \text { located) entity to vanish every five } \\ \text { minutes, then be brought into } \\ \text { existence one minute later. }\end{array} & \begin{array}{l}\text { Metaphysical } \\ \text { impossibility }\end{array} \\ \text { \# 4: } & \begin{array}{l}\text { It is not possible to travel faster } \\ \text { than light. }\end{array} & \begin{array}{l}\text { Laws-of-nature- } \\ \text { impossibility }\end{array}\end{array}$

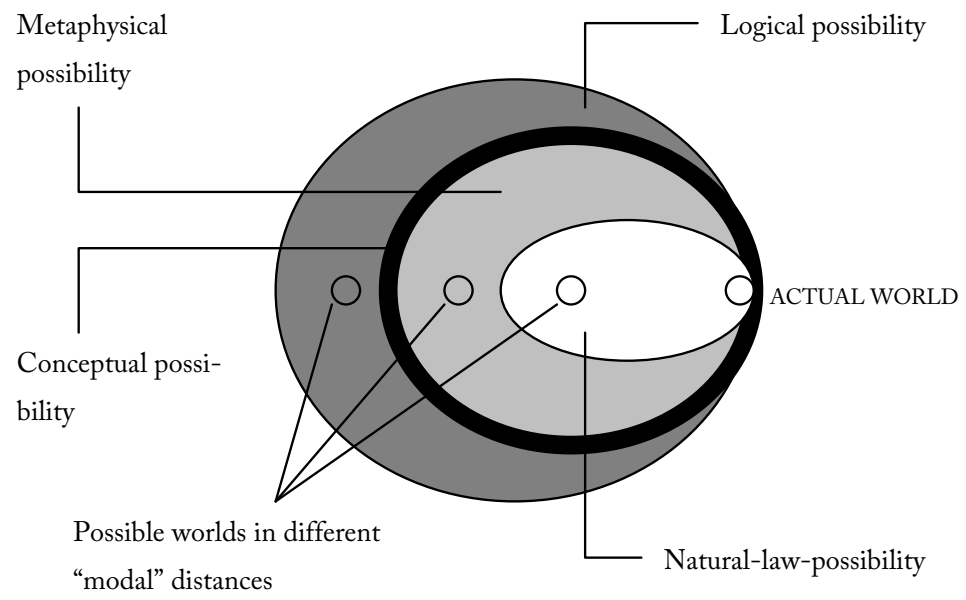

It is easy to see that the different degrees of possibility and impossibility are the outcome of conceivability and inconceivability on the one hand and some sort of content and input on the other hand. The claim that $p$ and not $-p$ are true simultaneously violates the most basic rule of communication. These rules have to be obeyed even before we start to think

${ }^{40}$ See Ernest J. Lowe, The Possibility of Metaphysics: Substance, Identity, and Time (Oxford: Clarendon Press, 1998) I6-2I. 
about conceivability. The fact that dolphins don't walk is not a matter of conceivability either, but rather a presupposition of conceivability insofar as conceivability needs stable concepts. Conceptual stability is the architecture that stabilizes the force of metaphysical necessity and impossibility, respectively. On the other side, metaphysical necessity is sensitive to the world and the universe as it is. This implies that we could imagine another world with other metaphysical laws. Nevertheless, a universe with different metaphysical laws would be disastrous for our concepts. In other words: It is the fact that metaphysical necessity is seated between concepts on the one side and input on the other side-input stemming from the ways in which we experience the world- which makes this kind of necessity so interesting. In contrast, natural-law-necessity does not exclude the imagination of another universe with different laws of nature, even if the metaphysical laws might be the very same. A world with different laws of nature might be un-inhabitable, but it would not be disastrous for the concept and metaphysics itself. If we discuss moral necessity we might, at first glance, think that the status of moral necessity is questionable. ${ }^{41}$

In a purified form, it should be a conceptual or a metaphysical necessity. This step is crucial for the problem of theodicy: As long as the limitation of God's omnipotence isn't based on conceptual or metaphysical necessity, there is no good reason for God's non-intervention. As a matter of fact, this is precisely the missing link in any Free-Will-Theodicy: to explain God's non-intervention in terms of metaphysical necessity (without

${ }^{41}$ Given the lively discussion of modalities with regard to their conceivability it seems hazardous to stick to the above introduced distinctions. Maybe only logical necessity/ possibility and nomological (laws-of-nature-) necessity/possibility should survive a process of further cleaning. Meixner's base-theory of modality would allow me to introduce the above mentioned examples as pointers to different bases $\left(b^{1}\right.$ to $\left.b^{4}\right)$ of modality and to develop different necessities and possibilities thereafter $\left(\square^{1} p\right.$ to $\square^{4} p$ and $\nabla^{1} p$ to $\nabla^{4} p$ ). While Meixner himself tends to reduce the number of bases significantly, I don't see why the above mentioned examples wouldn't support a more fine-grained distinction of modalities especially if we, as Meixner recommends, want to balance the epistemological, semantical, and metaphysical aspects of modal expressions. Cf. Meixner 2006, 83, I54-I55. But I am sure that "modal skeptics" are frightened if they take a look at the multiplication of modal degrees I have indicated. Maybe we should point out that any further discussion has to clarify if there is any form of modality beyond logical necessity/possibility and, if so, whether what remains is reducible to nomological necessity/possibility. 
thereby destroying God's divinity). To accomplish this, two strategies can be offered:

A) The first strategy still favors a classic concept of God which, nevertheless, includes a strong connection between divine will and divine essence. The latter has to serve as a basis for a restriction of divine omnipotence.

B) The second strategy is in favor of a more or less idealistic notion of God which forces us to rethink the usual notions of divine action and to replace these concepts with notions which hold that God cannot be conceived as capable of interfering immediately in the course of the world.

Strategy A) remains within the framework of FWD. One could find hints in Aquinas's theology that support the underlying idea: God's will is somehow bound by His essence; it is, however, not bound by some sort of necessity but by "fittingness." ${ }^{2}$ Nevertheless, fittingness creates a very specific form of necessity:

(NF) The realization of $e$ is most fitting if and only if its non-realization is logically possible and if its non-realization severely jeopardizes the dignity of the agent that has the power to bring about $e$.

To arrive at a strategy which can cope with the problem of theodicy we have to establish a modification of NF, namely, NFD and its complement NFD*:

(NFD) The realization of an event-type $\varphi$ is most fitting if and only if its non-realization is logically possible and if its non-realization severely jeopardizes the dignity of the divine agent that has the power to bring about tokens of $\varphi$.

${ }^{42}$ The most important example can be found in Aquinas's treatises on the Incarnation. Although, in his theory, each person of the Trinity could have become God incarnate it was most "fitting" that the eternal Word became God incarnate because of the attributes ascribed to the eternal Word. Cf. Thomas Aquinas, Summa Theologiae III q. 3 a. 8. 
(NFD*) The non-realization of an event-type $\varphi$ is most fitting if and only if its realization is logically possible and if its realization severely jeopardizes the dignity of the divine agent that has the power to bring about tokens of $\varphi$.

Classic Theology has argued that NFD* holds (as a general principle to describe the relation between God and the world) that, if God's creation is perfect, it does not really require specific acts of divine intervention. Frequent acts of intervention would violate God's dignity because they would prove the natural order to be imperfect. Another application of NFD* makes the pros and the range of this principle more obvious: Could God perform miracles that are un-witnessed and irrelevant for mankind (like chasing atoms at the surface of Jupiter)? Although there is no conceptual limitation that excludes God from performing such acts, these acts might go against God's dignity. This would be sufficient reason for God not to perform those acts. NFD* serves as a basis for a de-facto-limitation of God's omnipotence.

NFD* presents a sort of necessity, which is weaker than conceptual and, at first glance, metaphysical necessity. To lift it to the level of a metaphysical necessity/impossibility one would have to say that God's dignity is, in fact, God's essence. While dignity is something humans might lose without (unfortunately) losing too much, in God's case, dignity would be something God could not lose without losing his very nature and essence. Although this might strengthen the credibility of NFD* and the range of its applicability and possibly transform NFD* from a de-facto-limitation of divine omnipotence into a de-jure-limitation, one might still have trouble thinking of direct acts of divine intervention as acts that would instantiate $\varphi$-types of events as precluded by NFD*. In other words: It is hard to see why God would lose his dignity if he would perform acts of intervention (motivated by nothing less than mercy and compassion).

This is precisely the reason why strategy B) wants to take a step further. Its basic claim is a metaphysical limitation of God's omnipotence with respect to direct acts of divine intervention. This strategy seeks to find a basis which is significantly stronger than NFD*. But what kind of principle could serve as a basis for this step? Let us assume that the idea 
strategy B) is looking for might be some sort of Transcendent-BeingPrinciple:

(TBP) A transcendent and absolute being cannot directly intervene in the course of the world.

Strategy B) has a huge impact on a more classic understanding of God as a personal being. There are benefits to this strategy as well: As long as we think it might be possible that God has the power to intervene in the course of the world any time He wants, we are left with a challenging problem: Either God is not benevolent at all or $\mathrm{He}$ is not a reasonable agent because His interventions do not follow a rule or pattern. Strategy B) wants to establish an alternative view: God does not intervene directly in the course of the world. Saying this, one might ask whether strategy B) supports a more or less subtle form of deism.

To answer this question and to figure out where the proposed idea stands on the spectrum of available divine-action-theories, let us introduce a conceptual framework of possible concepts dealing with the idea of God's action or intervention, respectively. ${ }^{43}$ If we take a look at contemporary and classic philosophical treatises on the matter in question, we can distinguish seven different approaches ${ }^{44}$ :

${ }^{43}$ A very good overview of the debates concerning God's action in the world can be found in Reinhold Bernhardt, Was heißt "Handeln Gottes"? Eine Rekonstruktion der Lehre von der Vorsehung (Gütersloh: Kaiser, I999); Ute Lockmann, Dialog zweier Freiheiten: Studien zur Verhältnisbestimmung von göttlichem Handeln und Gebet (Innsbruck: Tyrolia, 2004) I67-252; Kreiner 2006, 312-342; von Stosch 2006, 23-85.

${ }^{44}$ Von Stosch offers a different system of categories. He distinguishes between a personal, a sapiential and a representational model of divine action. These distinctions were established by Bernhardt I999, 3I3-442. The personal model regards God as a personal agent. The second model thinks of God as somebody who established the order of the world, which might contain certain elements that may affect human agents (without overriding their freedom). The representational model thinks of certain events in the universe as icons, symbols and images of divine presence. In addition to Bernhardt, von Stosch included a distinction between the personal model of action and a "causative" model of efficiency, borrowing from Lockmann 2004. Cf. von Stosch 2006, 23-85. My distinction between seven models includes von Stosch's delineation but uses a simpler starting point, i.e. the basic difference between direct and indirect divine intervention. The difference between "personal" and "causative" models of agency is not very clear. And, as von Stosch points out himself, the distinction between "sapiential" and "representational" is not so clear either. The spectrum of seven approaches I have provided might be easier to grasp and easier to apply. 
(I) Straightforward Non-Interventionism

(2) Idealistic Non-Interventionism

(3) Process Interventionism

(4) Semi-Non-Interventionism

(5) Semi-Interventionism

(6) Interventionism

(7) Straightforward Omni-causation

Most certainly, answer (I) is a version of deism if this approach claims that God does not intervene in the course of the world and does not add anything further. Usually, any theologian who holds (I) includes some modifications that point to an indirect influence of God's will ${ }^{45}$ on the outcome and end of the world. ${ }^{46}$ Eventually, modifications like that turn (I) into something which comes closer to (4) and (5).

Model (2) is called "idealistic" because it has some affinity with approaches coming from German Idealism and was, as a matter of fact, spelled out by theologians that were inspired by German Idealism. This theory claims that God does not and cannot intervene in the course of the world because $\mathrm{He}$ is an absolute being. Therefore, approach (2) asks us to replace the phrase "intervention." Instead, we should talk about God's presence and about the means of representing the absolute in the world. ${ }^{47}$ Since the world participates in God, as approach (2) tells us, it is conceivable that God is present (i.e. represented) in the world without directly interfering

${ }^{45}$ One way to assure divine influence would be to say that God set up a master-plan for the direction his creation would take. But such an idea could destroy the intentions of strategy B) if the master-plan is deterministic because one might wonder why God's master-plan did not entail an event that, let's just say, killed Hitler before he became chancellor. Apparently, a master-plan-theory has to be subject to some sort of FWD. In this case, we should stop talking about a divine "master"-plan. Maybe, using analogies, it might be more appropriate to talk about certain "devices" God implanted in the universe-devices that point to God's will or that help us act on God's behalf.

${ }^{46}$ Cf.Maurice Wiles, God's Action in the World (London: SCM Press, 1986); for further discussions see Richard Sturch, The New Deism: Divine Intervention and the Human Condition (New York: St. Martin's Press, I990). In order to be fair one should take a closer look at the richness of Wiles' position. It is far from being a straightforward deism. Wiles proposes the idea of a divine plan that starts rolling at the beginning of creation. For a more detailed examination cf. von Stosch 2006, 9I-97.

${ }^{47}$ Cf. Bernhardt I999, 422-435. 
with the course of the universe. ${ }^{48}$ Questions that might arise from this perspective are concerned with the meaning of action-predicates, which are usually ascribed to God. If idealistic non-interventionism were true, how could we make sense of those action-predicates that seem to be a crucial part of religious language and any religious heritage?

Approach (3) has to deal with the same sort of problems since it tells us that God cannot intervene in the course of the world because he "emptied" his sovereign omnipotence right from the start in order to enable the free development of the world. Instead, as this version of divine action theory underlines, God tries, with His patient love, to "persuade" and "convince" the world to follow His intended course, in order to ensure a generally good end for the world. ${ }^{49}$

In contrast, model (4) comes closer to a traditional concept of God in saying that God cannot intervene in the course of the world since $\mathrm{He}$ is an absolute being and that $\mathrm{He}$, nevertheless, can influence the world with the help of a "supportive web" of secondary causes. ${ }^{50} \mathrm{It}$ is a further, rather metaphysical question how God as the first cause is related to the secondary causes in a way that maintains the integrity of God's intention and will, as well as the identity and partial independence of those instances that serve as secondary causes. Model (4), however, can collapse into a theory of divine omni-causation.

Problems like that are of no concern for version (5) since this version sticks to the idea of a possible divine intervention. However, God's

${ }^{48}$ Cf. Peter C. Hodgson, God in History. Shapes of Freedom (Nashville: Abingdon Press, I989); cf. the further discussion of idealistic positions in von Stosch 2006, 76-85. A very subtle theological version of idealistic-non-interventionism can be found in Hansjürgen Verweyen, Gottes letztes Wort: Grundriß der Fundamentaltheologie, $3^{\text {rd }}$ edit. (Regensburg: Pustet-Verlag, 2000), I54-I66. Verweyen's position is inspired by Fichte; cf. therefore Johann G. Fichte, "Die Wissenschaftslehre in ihrem allgemeinen Umrisse (I8Io), " in Fichtes Werke, Vol. 2 (Berlin: de Gruyter), §§ I-3.

${ }^{49}$ Cf. John Cobb and David R. Griffin, Process Theology: An Introductory Exposition (Philadelphia: Westminster Press, I976), 95-IIo.

${ }^{50}$ Cf. Béla Weissmahr, "Bemerkungen zur Frage der Möglichkeit eines nicht durch Geschöpfe vermittelten göttlichen Wirkens in der Welt," Zeitschrift für Katholische Theologie 96 (1974): I26-I30; a traditional hint in favor of this position can be found in Thomas Aquinas, Summa Theologiae I q. IO3 a. 3-a. 6 and q. IO4 a. 2; Thomas Aquinas, Summa contra Gentiles lib. I, 67-79. Theologically this view has been adopted by K. Rahner. Cf. Karl Rahner, Grundkurs des Glaubens: Einführung in den Begriff des Christentums (Freiburg i.B.: Herder-Verlag, 1976), 93-96. 
apparent non-intervention has to be justified. This can be done in two ways. One way would be to explain God's seeming lack of intervention by saying that the world would be a greater mess than it is if God did not act invisibly all the time. Although this is a theoretical possibility, it seems obvious that the amount of tragedies occurring in the world, does not really support this view. We could hardly call God a successful or reasonable agent, if He invisibly prevents many tragedies, while seemingly failing to prevent, or even guide, so many others. Another way to support version (5) would be to say that, although God can intervene in the course of the world, He decided to refrain from intervention to ensure human freedom, for the sake of human freedom..$^{51}$ If this were true, i.e. if God's non-intervention were based on an initial decision only, then one is entitled to ask whether God is morally responsible for the effects of his non-intervention. As contemporary action theories might point out: Under certain circumstances, non-intervention resembles action if the person in question had the ability and the freedom to intervene and to alter the course of what happened, as a matter of fact, without intervention. The only way out for model (5) would be an adaptation of NFD*.

Model (6) runs into comparable problems when it claims that God can intervene and does so whenever He wants and adds that God has performed acts of intervention throughout history, and continues to do so. ${ }^{52}$ One might ask how we can detect single events of God's intervention and, once we do so successfully, whether we might find some patterns of God's intervention to help us figure out a more general divine plan or strategy that gives meaning to the events in the world (including the suffering in the world). In case we should not be able to come up with such a pattern, a backfiring question is waiting for us: Can we call God a reasonable agent? If we have no response to that question, wouldn't we have to sign off on a mystery theology eventually?

Concept (7), however, embraces the mystery for the sake of a higher idea: God is the ultimate cause of everything-including every event and

51 Cf. Keith Ward, Divine Action: Examining God's Role in an Open and Emergent Universe (Philadelphia and London: Templeton Foundation Press 2007).

${ }_{52}$ Cf. William P.Alston, "Divine Action: Shadow or Substance," in The God Who Acts: Philosophical and Theological Explorations, ed. Thomas F. Tracy (Philadelphia: University Park, I994), 4I-62. 
every state of affairs in the world. But this answer-emphasized by rather Calvinist authors - truly endangers human freedom. Of course, with the sacrifice of human freedom the problem of theodicy gets an entirely different outline. One might question if there is any chance to resolve it at all on the basis of (7). The only way out that version (7) would have is to declare everything that God causes "good"-even if the goodness is something that goes beyond our understanding.

The above-mentioned strategy B), which is based on TBP, would presumably present itself as a combination of divine action theories (2) and (4). The foundation of these theories is the idea that God cannot intervene directly in the course of the world. Nevertheless, since TBP does not exclude indirect actions or mediated effects of God's will, some aspects of divine action can be preserved and even strengthened. Based on TBP, we could respond to the problem of theodicy as follows: To ask "Why doesn't God intervene?" elicits the answer: Because of the metaphysical impossibility of the immediate occurrence of the absolute, inside the event-course of the non-absolute universe. Despite this impossibility, we can nevertheless talk of God's presence by pointing, as some more or less idealistic divine-action-theorists do, to the shapes of freedom and love within the universe. But the appearances of these forms and shapes of the unrestricted are bound to the means that serve as a medium: Usually it is human beings who serve as the means to represent the absolute in the finite universe. So, God's "mediate intervention" is observable at any time when, for instance, finite human courage turns into unrestricted love, and when conditioned duty turns into the unrestricted will to diminish suffering. This comes close to the idealistic idea that the primary place of God's intervention is human conscience. ${ }^{53}$ On the other side: God cannot be present when humans refuse (based on their free will) to serve as the image of the absolute. At this point, it might be apparent that God's presence in the world is metaphysically bound to human freedom. Nevertheless, some kind of mystery still remains: If God wanted to avoid evil, he would have had to refuse creating the world at all. But, in the words of classic theology, the non-existence of the world would be much worse than the existence of the actual world.

${ }^{53}$ Cf. Johann G. Fichte, Ueber den Grund unseres Glaubens an eine göttliche Weltregierung, in Werke, Gesamtausgabe, Part I, Vol. 5 (Stuttgart-Bad Cannstatt: Frommann-Holzboog, I977), 347-357. 
Nevertheless, TBP doesn't say much about the occurrence of natural evils in the world. Expanding these concepts may be necessary to reach a more feasible point of departure. To arrive at an adequate perspective on nature, which helps us to come to terms with the problem of natural evils, we would have to think and imagine that the gift of freedom was spread out through the whole history of the universe. This is even more important if we want to have an answer to the problem of theodicy, especially, with respect to the problem of natural evil. As discussed earlier: It is not satisfying to say that natural evils are a result of natural laws; they are in accordance with these laws and are only in this respect the products of these laws. Once we see natural evil as a product of occasion as well, we cannot help but look at the atrocities in non-animated nature as a result of misguided possibilities. To "explain" this, we would have to turn to the rather speculative idea which not only holds that freedom is already part of non-animated nature but also that what one might call sin can be found in nature as well. ${ }^{54}$ Admittedly it sounds like nonsense to claim that a "quark" or "photon" makes some sort of decision. Perhaps we can soften the provocation if we, instead, propose that intentionality (in its most basic form as a mere tendency) is a constituent of the universe at every stage and level (e.g., to explain the strange phenomena of quantum mechanics, the category of "intentionality" is a rather promising basis). Yet, the combination of intentionality and freedom seems to be an implication of metaphysical or conceptual necessity. Even if we do not want to regard "quarks" and "photons" as living beings it might be worthwhile to look at the issue from a fresh perspective. To allude to Rahner's famous words: Matter is frozen spirit..$^{55}$ Along those lines one could say that matter is frozen intentionality and frozen freedom.

But, of course, one question remains: How can we support TBP? Is there any good reason to stick to it or even defend it and, therefore, to

${ }^{54}$ A comparable strategy can be found in Plantinga 1990, I53-I55 where Plantinga discusses the idea that natural evils could be caused by nonhuman agents (spirits, demons). I don't want to discuss the pros and cons of this idea. I just want to point to it as a strategy that tries to work out a synthesis between the idea of freedom on the one side and the problem of nature and natural evils on the other side.

${ }_{55}$ Cf. Karl Rahner, "Die Einheit von Geist und Materie im christlichen Glaubensverständnis," in Schriften zur Theologie, Vol. 6, ed. Karl Rahner, (Einsiedeln, Zürich and Köln: Benzinger-Verlag, I968), I85-214, 203. 
prefer strategy B) over strategy A)? TBP breathes the air of idealistic philosophy; it is not hard to find a prominent supporter: F. Schleiermacher. ${ }^{56}$ Before we take a closer look at Schleiermacher's concept, it must be underlined that Schleiermacher does not make use of these ideas for the problem of theodicy. As a matter of fact, Schleiermacher presents a version of classic "privation-boni"-theodicy ${ }^{57}$ in combination with a more or less Protestant idea of divine omni-causation. ${ }^{58}$ Nevertheless, Schleiermacher's remarks on the problem of immediate divine acts could help us to figure out the premises of TBP. In particular, two loosely connected trains of thought deserve our attention: Schleiermacher argues in favour of the dignity of the natural order of causes; his point is a subtle version of NFD*. He makes a distinction between absolute causes and finite causes-a distinction which might have an interesting impact on the concept of divine action. Schleiermacher's point of departure is an initial examination of divine omnipotence. He refers to some theological positions, which stress that the ability to perform extraordinary acts (such as immediate intervention by miracles) is a sign of divine omnipotence. Schleiermacher, however, seeks to defuse this impression. He underlines that this idea rests on a severe misconception: First of all, it presupposes a view of nature that regards nature and events, which are in accordance with the order or nature, as something that is not only devoid of God's presence but is almost anti-divine. If God is truly sustaining the universe then nature cannot be without a divine signature. ${ }^{59}$ Secondly, to assume that certain acts of intervention are required to get the development of the universe back on track, would seriously bring into question divine omnipotence and divine omniscience: If God has foreknowledge (at least in a Molinist ${ }^{60}$ sense), then He could have been aware of the problems (caused by his creation, or by the laws of nature at work in his creation) and could have initially

${ }^{56}$ Cf. D. Friedrich E. Schleiermacher, Der christliche Glaube nach den Grundsätzen der Evangelischen Kirche im Zusammenhange dargestellt (1830/3I), ed. Martin Redeker (Berlin and New York: de Gruyter, I999), § 46.

${ }^{57}$ For a discussion of the problems of this very classic approach to the problem of theodicy cf. Kreiner 1997, I25-I39.

58 Cf. Schleimeracher 1830/3I, § 48 .

${ }^{59}$ Cf. ibid. ${ }_{47}, 236$.

${ }^{60}$ Compare the discussion of this approach in Thomas Flint, Divine Providence: The Molinist Account (Ithaca and London: Oxford University Press, I998), II-7I. 
altered the outlines of the creation in order to avoid acts of immediate intervention. ${ }^{61}$ In other words: Immediate acts of intervention would disqualify God's initial omnipotence and omniscience. Admittedly, some parts of Schleiermacher's remarks sound a bit like a No-Better-World- or a No-Better-Laws-of-Nature-Theory. Only in this case, the connection between the world and God's action is made a bit more explicit. But Schleiermacher offers a second, rather independent train of thoughts to make his point: What would be the implication of the idea that God, the absolute cause, could act within the context of natural, i.e. finite causes? Schleiermacher's answer contains some important hints: If God, as the absolute cause, could act within the context of natural causes in order to bring about what cannot be brought about by natural causes (including finite persons such as human beings $\mathrm{s}^{62}$ ), then God would destroy the order and connection of natural causes with grave consequences for the past and future. With respect to the past, the chain of natural causes would be interrupted and put on hold; with respect to the future, the course of events would be significantly altered and based on something that could not be found in the natural order of causes (including the actions of human persons). ${ }^{63}$ Furthermore, any action of an absolute cause is an act of creation. But to think of an act of creation as being a supernatural link in a chain of natural causes (including the actions of human persons), would undermine the integrity of this chain. Moreover, it would seriously bring into question its existence since an act of creation would jeopardize, if not annihilate, what may have existed before. ${ }^{64}$ Schleiermacher's remarks can help us to modify TBP:

${ }^{61}$ Cf. Schleiermacher 1830/31, § 47, 235 .

${ }^{62}$ It is important to note that "natural" in Schleiermacher's sense does not mean naturalistic. The actions of free agents (such as human beings) are in accordance with the order of nature. In other words: Events are meant to be altered by beings that participate in nature and are parts of nature.

${ }^{63}$ Cf. Schleiermacher 1830/3I, § 47, 236, 237.

${ }^{64} \mathrm{Cf}$. Schleiermacher I830/3I, § 47, 240. Cf. parallel arguments in Béla Weissmahr, Gottes Wirken in der Welt: Ein Diskussionsbeitrag zur Frage der Evolution und des Wunders, (Frankfurt a.M.: Knecht-Verlag, I973); Gordon Kaufman, "On the Meaning of 'Act of God'," in God's Activity in the World, ed. Owen C. Thomas (Chico: Scholar's Press, I983), I37-I6r. 
$\left(\mathrm{TBP}^{*}\right)$ A transcendent and absolute being cannot intervene directly in the course of the world because whatever acts as an absolute cause cannot act as a relative cause (within the world).

For the idealistic approach presented by Schleiermacher, relative causes are finite causes that are somehow part of the spatio-temporal fabric of the universe. Since God is beyond space and time, TBP* is a consequence of an idealistic understanding of God's ontological primacy and eternity. ${ }^{65}$

It is important to notice that contemporary discussions of divine eternity seem to revolve around the problems presented by TBP*. At least in a reverse sense, these discussions give TBP* some credit. This is the reason why some atemporalists ${ }^{66}$ developed the idea of an eternal act of God (which unfolds with the development of the universe) and why some temporalists ${ }^{67}$ are eager to dismiss a traditional notion of eternity in order to defeat TBP*. Even if one questioned the validity of TBP* some of Schleiermacher's claims would still remain as thought-provoking questions: How could it be possible that God, as the absolute cause of being, acts within the framework of finite causes in order to replace finite causes every so often ${ }^{68}$ Apart from the fact that the admission of such a possibility might have disastrous consequences for the problem of theodicy, it is hard to imagine that God could act as a finite cause without becoming finite (i.e. spatio-temporal) Himself. If one wants to avoid any kind of non-interventionism (idealistic or otherwise) the only response one could give to this problem would be a reflection on

${ }^{65}$ Cf. Schleiermacher I830/3I, $§ 52$.

${ }^{66}$ Cf. Paul Helm, "Divine Timeless Eternity," in God and Time: Four Vierws, ed. Gregory E. Ganssle (Downers Grove: Inter Varistiy Press, 200I), 28-6o; Helm, "Response to Critics," in God and Time, 79-9I.

${ }^{67}$ Cf. Nicholas Wolterstorff, "Unqualified Divine Temporality," in God and Time, I87-213; Wolterstorff, "Response to Paul Helm," in God and Time, 68-78.

68 Of course, a whole bunch of questions will arise from any adaptation of TBP* since some might feel that this is straightforward deism. But a more careful reading of TBP* could defuse this impression: TBP* holds that God cannot act as a finite cause in the course of events; it does not exclude the possibility that God indirectly influences the course of the world. 
our lack of imagination. ${ }^{69}$ In any case, to cope with the problems of apparent divine non-intervention in the light of evil an interventionist has to pay the price for strategy A) unless he/she wants to hide behind a cloud of mystery.

${ }_{69}$ This would be Kreiner's response to non-interventionism; cf. Kreiner 2006, 325, 332. Kreiner himself has a strong inclination to support open theism and to stick to a NaturalLaw-Defense which conflates natural-law-necessity with logical necessity. Cf. Kreiner I997, 300-313, 364-379. Usually the so-called lack of imagination in non-interventionsim is more than counter-balanced by a very vivid imagination in interventionist approaches, cf. Ward 2007, II9-I33, I70-I89. 